\title{
Novel pili-like surface structures of Halobacterium salinarum strain R1 are crucial for surface adhesion
}

\author{
Gerald Losensky ${ }^{1}$, Lucia Vidakovic ${ }^{1}$, Andreas Klingl ${ }^{2,3}$, Felicitas Pfeifer ${ }^{1}$ and Sabrina Fröls ${ }^{1 *}$ \\ ${ }^{1}$ Microbiology and Archaea, Department of Biology, Technische Universität Darmstadt, Darmstadt, Germany \\ ${ }^{2}$ Cell Biology and LOEWE Research Centre for Synthetic Microbiology, Philipps-Universität Marburg, Marburg, Germany \\ ${ }^{3}$ Department of Biology I, Biozentrum, University of Munich, Planegg-Martinsried, Germany
}

\section{Edited by:}

Mechthild Pohlschroder, University

of Pennsylvania, USA

Reviewed by:

Scott Chimileski, University of

Connecticut, USA

Olivera Francetic, Institut Pasteur,

France

\section{*Correspondence:}

Sabrina Fröls, Microbiology and

Archaea, Department of Biology,

Technische Universität Darmstadt,

Schnittspahnstrasse 10, 64287

Darmstadt, Germany

e-mail: froels@bio.tu-darmstadt.de
It was recently shown that haloarchaeal strains of different genera are able to adhere to surfaces and form surface-attached biofilms. However, the surface structures mediating the adhesion were still unknown. We have identified a novel surface structure with Halobacterium salinarum strain R1, crucial for surface adhesion. Electron microscopic studies of surface-attached cells frequently showed pili-like surface structures of two different diameters that were irregularly distributed on the surface. The thinner filaments, $7-8 \mathrm{~nm}$ in diameter, represented a so far unobserved novel pili-like structure. Examination of the Hbt. salinarum R1 genome identified two putative gene loci (pil-1 and pil-2) encoding type IV pilus biogenesis complexes besides the archaellum encoding fla gene locus. Both pil-1 and pil-2 were expressed as transcriptional units, and the transcriptional start of pil-1 was identified. In silico analyses revealed that the pil-1 locus is present with other euryarchaeal genomes whereas the pil-2 is restricted to haloarchaea. Comparative real time qRT-PCR studies indicated that the general transcriptional activity was reduced in adherent vs. planktonic cells. In contrast, the transcription of pilB1 and pilB2, encoding putative type IV pilus assembly ATPases, was induced in comparison to the archaella assembly/motor ATPase ( $f l a /)$ and the ferredoxin gene. Mutant strains were constructed that incurred a flal deletion or flal/pilB1 gene deletions. The absence of flal caused the loss of the archaella while the additional absence of pilB1 led to loss of the novel pili-like surface structures. The $\Delta$ flal/ $\Delta$ pilB 1 double mutants showed a 10 -fold reduction in surface adhesion compared to the parental strain. Since surface adhesion was not reduced with the non-archaellated $\Delta$ flal mutants, the pil-1 filaments have a distinct function in the adhesion process.

Keywords: haloarchaea, deletion mutant, archaellum, Halobacterium salinarum, surface adhesion, archaeal type IV pili

\section{INTRODUCTION}

Various filamentous surface structures have been identified in Archaea mediating surface attachment or the formation of cellcell contacts. These are classified into archaeal type IV pili and non-type IV pili structures. The latter group consists of structurally very diverse representatives (Lassak et al., 2012). The SM1 euryarchaeon forms prickled filaments referred to as "hami" with a distal hook-like structure connecting the cells in a three-dimensional arrangement with regular distances (Moissl et al., 2005; Henneberger et al., 2006). Surface attached cells of Methanocaldococcus thermoautotrophicum show networks of thin filaments with diameters of $5.5 \mathrm{~nm}$, the Mth60 fimbriae (Thoma et al., 2008).

Abbreviations: ARF-TSS, Adaptor-and radioactivity-free identification of transcription start site; Fla, Flagella (archaella) accessory proteins; FlaI, Flagella (archaella) motor/biogenesis protein; Pil, Type IV pilus biogenesis complex; PilB, Type IV pilus biogenesis complex ATPase subunit; PilC, Type IV pilus biogenesis complex membrane subunit; qRT-PCR, Quantitative reverse transcription polymerase chain reaction; RT-PCR, Reverse transcription polymerase chain reaction; TEM, Transmission electron microscopy.
Type IV pili and type IV pili-like structures including the archaella (also called archaeal flagella, Jarrell and Albers, 2012) are present in several euryarchaeotal and crenarchaeotal species. The type IV pili biogenesis complexes of archaeal pili are related to those of bacteria (Peabody et al., 2003). The structural components of the pili (Pil) and archaella (Fla) include the assembly/motor-ATPase PilB/FlaI and the multispanning transmembrane protein PilC/FlaJ. These proteins represent in conjunction with the pilins or archaellins the core components of archaeal type IV pili systems (Pohlschröder et al., 2011). Archaeal type IV pili mediate versatile functions like motility, adhesion to biotic or abiotic surfaces, cell-cell connections, biofilm formation and architecture, as well as DNA-exchange (Lassak et al., 2012). A common adhesion strategy has not been observed for Archaea so far. In the case of Pyrococcus furiosus, the multifunctional archaella are sufficient to mediate surface adhesion and the formation of cell-cell connections (Näther et al., 2006). Surface adhesion of Haloferax volcanii solely depends on pili and does not require the presence of the archaella (Tripepi et al., 2010). For Methanococcus maripaludis and Sulfolobus solfataricus pili and 
archaella are both necessary for the attachment to a variety of abiotic surfaces (Zolghadr et al., 2010; Jarrell et al., 2011).

By a screening approach with various haloarchaeal strains we demonstrated that surface adhesion is found with the genera Halobacterium, Haloferax, Halorubrum, and Halohasta. Different type strains, their derivatives and natural isolates of Halobacterium salinarum are able to adhere to abiotic surfaces, which supports the subsequent formation of biofilms. Initial studies by transmission electron microscopy (TEM) of surface attached Hbt. salinarum DSM $3754^{\mathrm{T}}$ cells showed various filamentous structures on the surface (Fröls et al., 2012). However, the structures mediating surface adhesion are still unknown. In the case of Hbt. salinarum, the archaella are the only surface structures described to date (Alam and Oesterhelt, 1984). These filaments are $10 \mathrm{~nm}$ in diameter, polarly localized and enable the cells to swim by an ATP-driven rotation (Alam and Oesterhelt, 1984; Cohen-Krausz and Trachtenberg, 2002; Streif et al., 2008).

The aim of the present work was to identify the filamentous structures involved in surface adhesion of Hbt. salinarum strain R1 cells in vitro and in vivo. TEM analyses were used to identify and classify filamentous structures present with surface attached cells of Hbt. salinarum R1. A novel type of filamentous structures was observed. The genome sequence was analyzed to search for putative type IV pili gene loci encoding filamentous surface structures other than archaella and two putative type IV pilus biogenesis ( $p i l$ ) gene loci were identified. The transcripts were determined and the transcriptional activity of the assembly/motor-ATPases pilB/flaI genes was examined by comparative real time qRT-PCR analyses in planktonic and surface attached cells. Deletion mutants were constructed to investigate the presence of filamentous structures in dependency of flaI and pilB1 as well as elucidating their role with regard to motility and surface adhesion.

\section{MATERIALS AND METHODS STRAINS AND GROWTH CONDITIONS}

Hbt. salinarum strains R1, DSM 3754 ${ }^{\mathrm{T}}$, PHH1, PHH4, SB3, GN101, and NRC-1 (strain details were listed in Table 1) were grown aerobically at $37^{\circ} \mathrm{C}$ in complex medium $(250 \mathrm{~g} \mathrm{NaCl}, 20 \mathrm{~g}$ $\mathrm{MgSO}_{4} \times 7 \mathrm{H}_{2} \mathrm{O}, 2 \mathrm{~g} \mathrm{KCl}, 15 \mathrm{~g}$ Oxoid peptone, $50 \mathrm{ml} 1 \mathrm{M}$ Tris/HCl $\mathrm{pH} 7.5$ per liter). For cultivation of planktonic and adherent cells an overnight culture with an optical density at $600 \mathrm{~nm}\left(\mathrm{OD}_{600}\right)$ of 0.3 was used for inoculation. Before growth the $\mathrm{OD}_{600}$ was set to 0.002 . Planktonic cells were grown in cultures shaking at $180 \mathrm{rpm}$ and harvested during the exponential growth phase at $\mathrm{OD}_{600} 0.3$ for RNA preparation and $\mathrm{OD}_{600} 0.5$ for DNA preparation. Adherent cells were grown in large Petri dishes $(150 / 20 \mathrm{~mm}$, Sarstedt) as static cultures. After 6 days of growth the supernatant was discarded and the dishes were washed three times with $50 \mathrm{~mL}$ salt water (complex medium without peptone) to remove nonadhering cells. Adherent cells were scraped off the dishes using a spatula.

\section{TRANSMISSION ELECTRON MICROSCOPY (TEM)}

Planktonic Hbt. salinarum R1 cells were grown at $37^{\circ} \mathrm{C}$ to $\mathrm{OD}_{600}$ 0.8 , fixed with $1 \%$ glutaraldehyde for $30 \mathrm{~min}$ at room temperature and applied onto carbon coated copper grids (400 mesh,
Table 1 | Strains and plasmids used for the studies.

\begin{tabular}{|c|c|c|}
\hline Strain & Origin & References \\
\hline $\begin{array}{l}\text { Hbt. salinarum R1 } \\
\text { (DSM 671, ATCC } \\
\text { 2934) }\end{array}$ & Derived from DSM670 & Pfeiffer et al., 2008b \\
\hline $\begin{array}{l}\text { Hbt. salinarum DSM } \\
3754^{\top} \text { (ATCC 33171) }\end{array}$ & Type strain & $\begin{array}{l}\text { Elazari-Volcani } 1957 \\
\text { (Gruber et al., 2004). }\end{array}$ \\
\hline Hbt. salinarum $\mathrm{PHH} 4$ & Derived from $\mathrm{PHH} 1$ & $\begin{array}{l}\text { Pfeifer and Blaseio, } \\
1989\end{array}$ \\
\hline Hbt. salinarum SB3 & Natural isolate & Ebert et al., 1984 \\
\hline $\begin{array}{l}\text { Hbt. salinarum } \\
\text { GN101 }\end{array}$ & Natural isolate & Ebert et al., 1984 \\
\hline $\begin{array}{l}\text { Hbt. salinarum } \\
\text { NRC-1 } \\
\text { (ATCC 700922) }\end{array}$ & Type strain & Pfeiffer et al., 2008b \\
\hline Hbt. salinarum $\mathrm{PHH} 1$ & Derived from DSM670 & Pfeifer et al., 1988 \\
\hline $\begin{array}{l}\text { Hbt. salinarum R1 } \\
\Delta \text { flal }\end{array}$ & $\begin{array}{l}\text { In frame deletion of } \\
\text { OE2380R (1890 bp) }\end{array}$ & This study \\
\hline $\begin{array}{l}\text { Hbt. salinarum R1 } \\
\Delta \text { flal/ } \Delta \text { pilB1 }\end{array}$ & $\begin{array}{l}\text { Derived from } \mathrm{Hbt} \text {. } \\
\text { salinarum R1 } \Delta \text { flal } \\
\text { In frame deletion of } \\
\text { OE2215R (1758 bp) }\end{array}$ & This study \\
\hline Plasmid & Relevant characteristics & References \\
\hline pMKK100 & $\begin{array}{l}\text { E. coli/Hbt. salinarum } \\
\text { shuttle plasmid, } \\
\text { mevinoline resistance, } \\
\text { bgaH reporter gene }\end{array}$ & $\begin{array}{l}\text { Koch and Oesterhelt, } \\
2005\end{array}$ \\
\hline pMKK100- $\Delta$ flal & $\begin{array}{l}\text { Contains fusion fragment } \\
\text { of the up- ( } 496 \mathrm{bp} \text { ) and } \\
\text { downstream ( } 440 \mathrm{bp}) \\
\text { regions of OE2380R }\end{array}$ & This study \\
\hline pMKK100- $\Delta$ pilB1 & $\begin{array}{l}\text { Contains fusion fragment } \\
\text { of the up- ( } 492 \mathrm{bp} \text { ) and } \\
\text { downstream ( } 601 \mathrm{bp}) \\
\text { regions of OE } 2215 \mathrm{R}\end{array}$ & This study \\
\hline
\end{tabular}

Plano $\mathrm{GmbH}$ ) for $30 \mathrm{~s}$. For the investigation of adherent cells, carbon coated gold grids ( 400 mesh, Plano $\mathrm{GmbH}$ ) were placed in a freshly inoculated culture and incubated in static culture at $42^{\circ} \mathrm{C}$ for 10 days. Adherent cells were fixed with $2 \%$ paraformaldehyde $\mathrm{w} / \mathrm{v}$ and $1 \%$ glutaraldehyde w/v over night at $4^{\circ} \mathrm{C}$. Samples were washed eight times with double distilled water to avoid the formation of salt crystals. After removing excess fluid using filter paper, samples were contrasted with $2 \%$ uranyl acetate ( $\mathrm{pH} 6$, containing maleic acid) for $60 \mathrm{~s}$ and stored in a desiccator containing silica gel. The software ImageJ (National Institutes of Health, http://rsb. info.nih.gov/ij/index.html) was used for measuring the diameter in $\mathrm{nm}$ of visible surface appendages.

\section{IN SILICO ANALYSES}

The somewhat similar sequences (blastn), position-specific iterated (psi-blast) and protein-protein (blastp) BLAST ${ }^{\circledR}$ alignment search tools were used to analyze gene and protein identities, functions and presence with other genomes (NCBI Resource Coordinators, 2014). Additional analyses were performed using 
HaloLex (Pfeiffer et al., 2008a), the UCSC Archaeal Genome Browser (Schneider et al., 2006; Chan et al., 2012) and SMART (Schultz et al., 1998; Letunic et al., 2012). The predictions of transmembrane helices in proteins were performed using the software TMHMM Server v. 2.0 (Krogh et al., 2001), archaeal class III (type IV pilin-like) signal peptides by use of FlaFind 1.2 (Szabo et al., 2007; Esquivel et al., 2013) and the secondary structures of single stranded nucleic acids by the software mfold (Zuker, 2003).

\section{RNA PREPARATION}

Total RNA was isolated from planktonic and adherent cells by standard acid guanidinium thiocyanate-phenol-chloroform extraction (Chomczynski and Sacchi, 2006). Genomic DNA was removed by treatment with RNase-free DNaseI (\# EN0523, Thermo Fisher Scientific) for $4 \mathrm{~h}$ at $37^{\circ} \mathrm{C}$. Purified RNA was used to generate complementary DNA (cDNA).

\section{REVERSE TRANSCRIPTION POLYMERASE CHAIN REACTION (RT-PCR)}

For transcript mapping $40 \mu \mathrm{g}$ purified RNA were reversely transcribed into cDNA using Random Hexamer Primers (\# SO142, Thermo Fisher Scientific) and RevertAid Reverse Transcriptase (\# EP0441, Thermo Fisher Scientific) in a total volume of $160 \mu \mathrm{L}$ according to the manufacturer's protocol. To investigate co-transcription of neighboring genes, oligonucleotides were designed to amplify fragments encompassing the intergenic region and overlapping adjacent genes (see Table S1 and Figure 2). In case of co-transcription, these primers will lead to PCR products using cDNA as template. RT-PCR analysis of pil1 was performed using Taq/Pfu-polymerase mix 19:1 (\# EP0702 and \# EP0502, Thermo Fisher Scientific) (initial step $300 \mathrm{~s}$ at $95^{\circ} \mathrm{C}, 35$ cycles of $60 \mathrm{~s}$ at $95^{\circ} \mathrm{C}, 90 \mathrm{~s}$ at $54^{\circ} \mathrm{C}$ to $64^{\circ} \mathrm{C}, 135 \mathrm{~s}$ at $72^{\circ} \mathrm{C}$, end step $300 \mathrm{~s}$ at $72^{\circ} \mathrm{C}$ ) according to the manufacturer's protocol. For analysis of pil-2 the more sensitive Q5-polymerase (\# M0491L, New England Biolabs) was used (initial step $300 \mathrm{~s}$ at $98^{\circ} \mathrm{C}, 35$ cycles of $10 \mathrm{~s}$ at $98^{\circ} \mathrm{C}, 30 \mathrm{~s}$ at $49^{\circ} \mathrm{C}$ to $60^{\circ} \mathrm{C}, 40 \mathrm{~s}$ at $72^{\circ} \mathrm{C}$, end step $120 \mathrm{~s}$ at $72^{\circ} \mathrm{C}$ ). Control reactions were performed using a similar RNA sample without reverse transcription to exclude a possible genomic DNA contamination. PCR was performed to validate the amplicon size and specificity of the oligonucleotides using Hbt. salinarum R1 genomic DNA as template.

\section{TRANSCRIPTION START SITE DETERMINATION (ARF-TSS)}

The transcription start site (TSS) was determined using the Adaptor-and radioactivity-free (ARF-TSS) method described by Wang et al. (2012). Purified RNA was used to generate first strand cDNA using the pilB1 gene specific oligonucleotide TSS-pil-1-P1RT (see Table S1 for oligonucleotide sequences) complementary to a sequence located 160 bases downstream of the annotated start codon of OE2215R. The cDNA was circularized using T4 RNA ligase (\# EL0021, Thermo Fisher Scientific) to fuse the $3^{\prime}$ and the $5^{\prime}$-end of the cDNA. The circularized cDNA served as template for PCR using the two diverging oligonucleotides TSSpil-1-P2-PCR and TSS-pil-1-P3-PCR, binding between the sites of the gene specific oligonucleotide and the TSS. PCR products were inserted into $\mathrm{pCR}^{\circledR}$ 2.1-TOPO ${ }^{\circledR}$ using TOPO TA Cloning ${ }^{\circledR}$ Kit for Sequencing (\# 450641, Invitrogen) following the protocol of the manufacturer and the resulting constructs were used for sequence analysis with standard M13 oligonucleotides.

\section{DNA PREPARATION AND SOUTHERN ANALYSIS}

For preparation of genomic DNA, $2 \mathrm{~mL}$ cell culture $\left(\mathrm{OD}_{600} 0.5\right)$ were sedimented by centrifugation, the cell pellet resuspended in $100 \mu \mathrm{L}$ salt water and lysed osmotically by the addition of $900 \mu \mathrm{L}$ TEN-buffer (100 mM NaCl, 1mM EDTA, $20 \mathrm{mM}$ Tris/HCl $\mathrm{pH}$ 8.0). Standard phenol/chloroform extraction was performed followed by DNA precipitation using isopropyl alcohol. For Southern analysis $3 \mu \mathrm{g}$ of genomic DNA cut with Aat II were separated on $0.7 \%$ agarose gels and blotted on Roti ${ }^{\circledR}$ Nylon membranes (pore size $0.2 \mu \mathrm{m}$, Carl Roth GmbH \& Co. KG). Southern blots were hybridized in standard hybridization buffer with digoxigenin-labeled DNA-probes and detected by use of Antidigoxigenin-alkaline phosphatase Fab fragments (\# 11093274910, Roche) in combination with the Phototope ${ }^{\circledR}$-Star Detection Kit (\# N7020S, New England Biolabs) according to the manufacturer's protocols. A digoxigenin DNA labeling Kit (\# 11277065910, Roche) was used to produce DNA-probes by standard PCR using genomic DNA of Hbt. salinarum R1 as template in combination with the following oligonucleotides: pil-1-probe-fwd and pil-1probe-rev producing a $1541 \mathrm{bp}$ PCR product; pil-2-probe-fwd and pil-2-probe-rev producing a $686 \mathrm{bp}$ PCR product (see Table S1 for oligonucleotide sequences).

\section{QUANTITATIVE REVERSE TRANSCRIPTION POLYMERASE CHAIN REACTION (qRT-PCR)}

For qRT-PCR $5 \mu \mathrm{g}$ RNA supplemented with $1 \mathrm{ng}$ of an external standard RNA in a total volume of $20 \mu \mathrm{L}$ were used to generate the cDNA. External standard RNA (length $1790 \mathrm{nt}$ ) was produced by in vitro transcription of the bgaH gene, using T7 RNA polymerase (\# EP0111, Thermo Fisher Scientific) according to the manufacturer's protocol. qRT-PCR analysis was performed using the StepOne ${ }^{\mathrm{TM}}$ Real-Time PCR System (Applied Biosystems) and the SensiFast ${ }^{\mathrm{TM}}$ SYBR Hi-ROX Kit (\# BIO-92005, Bioline) according to the manufacturer's protocol. Using the StepOne ${ }^{\mathrm{TM}}$ software v2.0 the $\Delta \Delta \mathrm{C}_{\mathrm{T}}$-method was applied to calculate relative expression changes of the target genes in adherent cells compared to their expression in planktonic cells (Schmittgen and Livak, 2008). $C_{\mathrm{T}}$-values were determined by the StepOne ${ }^{\mathrm{TM}}$ software (Applied Biosystems). $C_{\mathrm{T}}$-values of the housekeeping genes rpoB1 (OE4741R) and aef2 (OE4729R) were normalized to the external standard $b g a H$ to investigate the general transcriptional activity of the cells. $C_{\mathrm{T}}$-values of the target genes were normalized to the housekeeping gene rpoB1 (Bleiholder et al., 2012). Samples were examined in triplicates. Control reactions checking for genomic DNA contamination were done as described before.

\section{CONSTRUCTION OF DELETION MUTANTS}

The construction of deletion mutants was performed using the pop-in/pop-out strategy (Koch and Oesterhelt, 2005). Approximately $500 \mathrm{bp}$ upstream (US) and downstream (DS) of the gene of interest were amplified from genomic DNA (initial step $300 \mathrm{~s}$ at $95^{\circ} \mathrm{C}, 30$ cycles of $60 \mathrm{~s}$ at $95^{\circ} \mathrm{C}, 60 \mathrm{~s}$ at $58^{\circ} \mathrm{C}$ to $72^{\circ} \mathrm{C}, 30 \mathrm{~s}$ to $150 \mathrm{~s}$ at $72^{\circ} \mathrm{C}$, end step $600 \mathrm{~s}$ at $72^{\circ} \mathrm{C}$ ) and fused 
by PCR (initial step $300 \mathrm{~s}$ at $95^{\circ} \mathrm{C}, 60 \mathrm{~s}$ at $60^{\circ} \mathrm{C}, 60 \mathrm{~s}$ at $72^{\circ} \mathrm{C}, 10$ cycles of $60 \mathrm{~s}$ at $95^{\circ} \mathrm{C}, 60 \mathrm{~s}$ at $60^{\circ} \mathrm{C}, 30 \mathrm{~s}$ at $72^{\circ} \mathrm{C}$, end step $600 \mathrm{~s}$ at $72^{\circ} \mathrm{C}$ ). Oligonucleotides used are listed in Table S1. The fused US/DS PCR products were cloned into pMKK100 (Koch and Oesterhelt, 2005). Polyethylenglycol-mediated transformation of Hbt. salinarum R1 was carried out (Dyall-Smith, 2008), followed by red-blue screening $(6 \mu \mathrm{g} / \mathrm{mL}$ of mevinolin and $40 \mu \mathrm{g} / \mathrm{mL}$ of $\mathrm{X}$-gal). Blue transformants were used to inoculate liquid cultures without mevinolin (to induce the pop-out) for three subsequent cultivations with complex medium and plated on agar media containing $40 \mu \mathrm{g} \mathrm{mL}^{-1} \mathrm{X}$-gal. Red colonies were selected for the absence of the gene of interest and verified at the site of the deletion by PCR using genomic DNA (initial step $300 \mathrm{~s}$ at $95^{\circ} \mathrm{C}, 30$ cycles of $60 \mathrm{~s}$ at $95^{\circ} \mathrm{C}, 60 \mathrm{~s}$ at $58^{\circ} \mathrm{C}$ to $72^{\circ} \mathrm{C}, 30 \mathrm{~s}$ to $150 \mathrm{~s}$ at $72^{\circ} \mathrm{C}$, end step $600 \mathrm{~s}$ at $72^{\circ} \mathrm{C}$ ) followed by sequencing with US/DS flanking oligonucleotides (listed in Table S1). The deletion strains and plasmids are listed in Table $\mathbf{1 .}$

\section{MOTILITY ASSAY}

To investigate swimming motility, Hbt. salinarum R1 and the two deletion mutants were grown in semi-solid medium containing $0.3 \%$ agar (w/v) (Patenge et al., 2001). $10 \mu \mathrm{L}$ of a liquid culture $\left(\mathrm{OD}_{600} 0.3\right)$ were placed in the center of the agar surface and incubated over $96 \mathrm{~h}$ in the dark at $42^{\circ} \mathrm{C}$. The diameter of each motility halo was measured in $\mathrm{cm}$ using the software ImageJ (National Institutes of Health, http://rsb.info.nih.gov/ij/index.html). The average motility halo and standard deviation was calculated from 19 replicates per strain.

\section{SURFACE ADHESION ON GLASS}

Hbt. salinarum strains were grown in Petri dishes $(92 / 16 \mathrm{~mm}$, Sarstedt) containing $15 \mathrm{~mL}$ complex medium inoculated with cells from the exponential growth phase $\left(\mathrm{OD}_{600} 0.3-0.5\right)$. The starting culture was set to a calculated $\mathrm{OD}_{600}$ of 0.002 before the cells were grown at $42{ }^{\circ} \mathrm{C}$ for 10 days. Coverslips were inserted into the media to allow adherence on glass. Prior the microscopic analyses, overgrown coverslips were washed three times with salt water (complex medium without peptone) to remove all nonadherent cells. Microscopic analyses were performed using a Zeiss Axioskop 2 (camera AxioCam MRm, software AxioVision). The software ImageJ (National Institutes of Health, http://rsb.info. nih.gov/ij/index.html) was used to select (using the color-based thresholding function) and measure (using the analyze particles function) the percentage of surface coverage. The quantifications are based on the surface-attached cells of six independent visual fields of separate coverslips, from at least two independent inoculated cultures. Significances ( $p$-values) of the percentage of surface coverage between the parental and mutant strains were calculated by an unpaired, two-tailed $t$-test.

\section{RESULTS}

\section{IDENTIFICATION OF SURFACE STRUCTURES PRESENT WITH SURFACE} ATTACHED CELLS OF Hbt. salinarum R1

TEM was used to investigate the presence of filamentous structures with surface attached cells of $\mathrm{Hbt}$. salinarum strain R1 grown on carbon coated gold grids for 10 days (Figure 1A).
Numerous long (> $50 \mathrm{~nm}$ ) and flexible pili-like surface structures were observed between the cells on the carbon surface (Figures 1B,C). The majority of the surface structures were distributed irregularly as single filaments. Many of the filaments originated from the cell poles, but for most of those no origin could be determined. Differences regarding the diameter of single filaments were noticed at higher magnification (Figures 1D,E). The diameters of 100 filaments of at least 10 to 15 photographs were determined using the software ImageJ. The diameters of the filaments were in minimum between 5 and $6 \mathrm{~nm}$ and in maximum 14 and $15 \mathrm{~nm}$. The frequency distribution showed two dominant diameters of $7-8 \mathrm{~nm}$ and $10-11 \mathrm{~nm}$ both with a maximum of $20 \%$ (Figure 1F). These data suggested the presence of two different filamentous surface structures in Hbt. salinarum R1 with average diameters of $7.6 \pm 0.7 \mathrm{~nm}$ (calculated on the categories 6 to $9 \mathrm{~nm}, n=30$ ) and $10.3 \pm 0.8 \mathrm{~nm}$ (calculated on the categories 9 to $12 \mathrm{~nm}, n=46$ ). The width of the thicker filaments is consistent with the archaella of Hbt. salinarum R1 (Alam and Oesterhelt, 1984; Cohen-Krausz and Trachtenberg, 2002), whereas the thinner filaments might represent a novel pili-like surface structure.

\section{IN SILICO IDENTIFICATION AND TRANSCRIPTION OF PUTATIVE TYPE IV PILI GENE LOCI}

The assembly/motor-ATPase FlaI (OE2380R) of the archaellum encoding gene cluster was used as starting point to identify further putative type IV pili biogenesis complex gene loci in the genome sequence of Hbt. salinarum R1 (NC_010364.1, Pfeiffer et al., 2008b). By blastp analyses two putative type IV pili assembly ATPases (PilB) homologs of FlaI were identified which share an amino acid identity of 35 and $28 \%$ (query coverage 62 and $48 \%, e$ value $6 e-75$ and $5 e-21)$, respectively. These proteins were termed PilB1 (OE2215R) and PilB2 (OE1347R) based on the amino acid identity compared to FlaI. Both proteins contain a conserved VirB11 ATPase domain found with archaeal type IV pili secretion systems (arCOG01817, arCOG01818). The genes pilB1 and pilB2 (encoding the putative assembly ATPases) were located adjacent to genes coding for putative multispanning transmembrane archaella/pilus assembly proteins (arCOG01808, arCOG01810) possessing 7 and 9 predicted transmembrane helices. These genes were termed pilC1 (OE2212R) and pilC2 (OE1344R), with the latter gene having an in-frame stop codon. The encoded protein PilC1 only has a significant amino acid identity of $23 \%$ (query coverage $24 \%, e$-value $2 \mathrm{e}-04)$ to the archaellar transmembrane protein FlaJ (OE2379R).

Reverse transcriptase polymerase chain reaction analyses (RTPCR) were performed to determine whether the corresponding genes of the putative type IV pili assembly ATPases pilB1 (OE2215R), pilB2 (OE1347R) and putative transmembrane proteins pilC1 (OE2212R), pilC2 (OE1344/42R) are transcribed. DNaseI-treated total RNA of Hbt. salinarum R1 was used for the generation of the cDNA. No amplification products were observed with RNA, which was not reversely transcribed as template, confirming the absence of DNA contaminations in the sample. Gene specific oligonucleotides were used for the RT-PCR reaction (listed in Table S1) to amplify gene-to-gene overlapping fragments of adjacent genes. The RT-PCR studies confirmed 


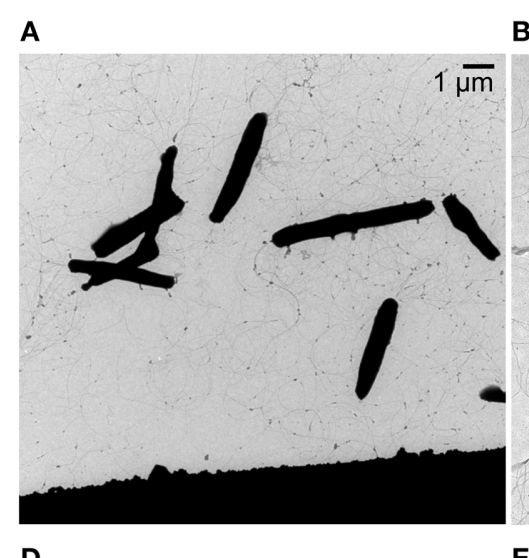

D

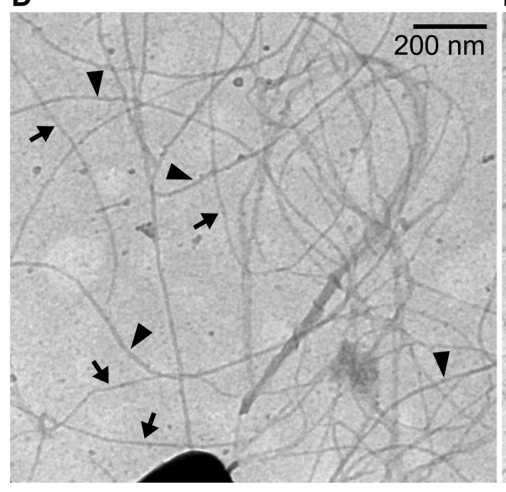

B

C

B

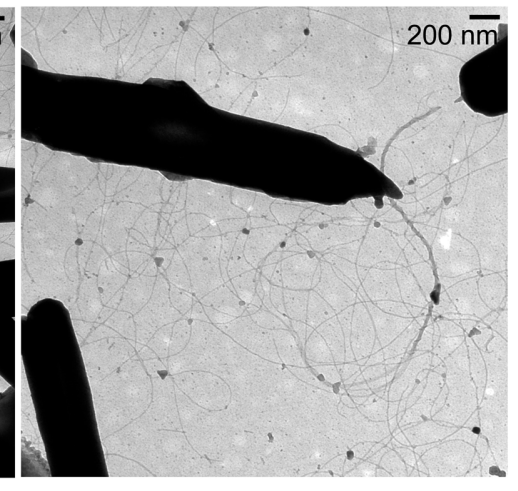

E $F$

$\mathbf{F}$
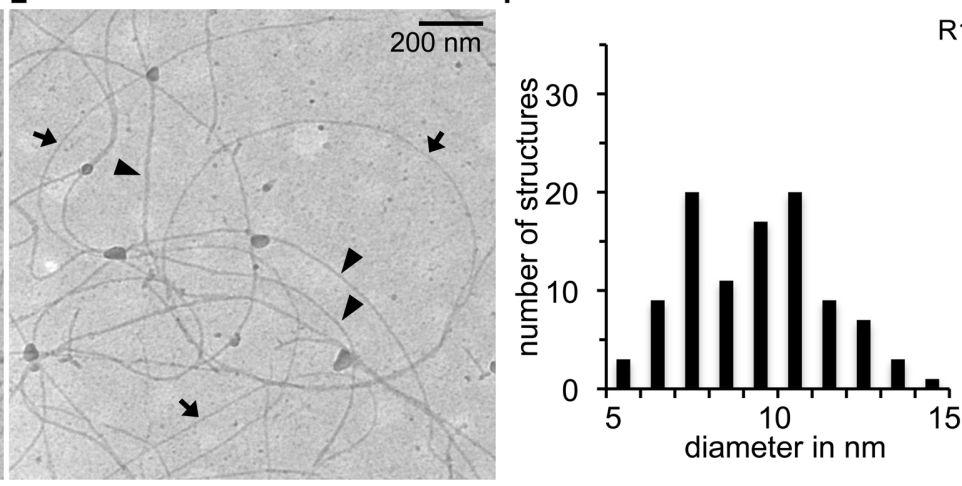

R1

FIGURE 1 | TEM analyses of $\boldsymbol{H b t}$. salinarum $\mathrm{R} 1$ attached to surfaces.

(A) Surface attached cells grown for $10 \mathrm{~d}$ at $42^{\circ} \mathrm{C}$ on carbon coated gold grids. (B,C) Pili-like surface structures observed on the carbon surface. (D,E)
Determination of different diameters of pili-like structures. Arrow heads, wide diameters; arrows, thinner structures. (F) Frequency distribution observed with different diameters determined for 100 surface structures. the transcriptional activity of the identified pilB1, pilC1, and pilB2, pilC2 genes (Figures 2A,C). RT-PCR analyses of the gene regions upstream of $p i l B 1 / 2$ and downstream of $p i l C 1 / 2$ yielded the transcriptional unit of the putative $p i l-1 / 2$ gene loci. The transcript of the pil-1 locus $(4.4 \mathrm{kbp})$ spans the three open reading frames OE2215R, OE2212R, and OE2210R (Figure 2A). Minor or not detectable amplification products were observed for the oligonucleotides combination used to amplify the overlapping gene region of OE2217R and OE2215R. Therefore, the adaptorand radioactivity-free (ARF) method by Wang et al. (2012) was used to determine the transcriptional start site of the pil-1 locus (Wang et al., 2012). The sequence analyses of four PCR-products identified the guanine, $4 \mathrm{nt}$ downstream of the predicted AUG as start site the of pilB1 transcript. A GUG motif as alternative translational start codon is present at position $+76 \mathrm{nt}$, implying the presence of a $5^{\prime}$-untranslated region $\left(5^{\prime}\right.$-UTR) with pilB1 (Figure 2B). With regard to the pil-2 locus $(6.9 \mathrm{kpb})$, cotranscription of seven open reading frames, OE1347R through OE1332R, was determined (Figure 2C). These include three genes encoding potential prepilins (OE1340R, OE1336R, OE1334R) containing type IV pilin-like signal peptides as predicted by the software FlaFind 1.2. No potential prepilin encoding genes were found with the pil-1 locus or within the surrounding genomic region of about $100 \mathrm{kbp}$. A schematic illustration summarizing the results for the pil-1 and pil-2 loci is given in Figure S1.

\section{PRESENCE OF THE pil-1 AND pil-2 GENE LOCI IN OTHER HALOARCHAEAL GENOMES}

Southern analyses using gene specific digoxigenin labeled pilB1/C1 and pilB2 probes were carried out to investigate the occurrence of the pil-1 and pil-2 loci in seven different $\mathrm{Hbt}$. salinarum strains. The type strain DSM $3754^{\mathrm{T}}$, the three closely related wild type strains $\mathrm{R} 1, \mathrm{NRC}-1, \mathrm{PHH} 1$, and the $\mathrm{PHH} 1$ derivative $\mathrm{PHH} 4$ (strain information is given in Table 1) as well as two natural isolates derived from salt flats in San Francisco (SB3) or Guerrero Negro (GN101) sharing 16S rRNA sequence identities of 98 to $99 \%$ to $\mathrm{Hbt}$. salinarum R1 but possessing distinct plasmid populations different from the three wild type strains (Ebert et al., 1984). All these species differ in their ability to adhere to surfaces. Hbt. salinarum R1 and DSM $3754^{\mathrm{T}}$ show strong, $\mathrm{Hbt}$. salinarum $\mathrm{PHH} 4$ and SB3 moderate adhesion to a plastic surface, whereas no significant adhesion is observed for Hbt. salinarum NRC-1, PHH1, and GN101 (Fröls et al., 2012).

To investigate the presence of the pil-1 and pil-2 loci in the genomes of these Hbt. salinarum strains, total DNA was isolated and hydrolyzed with the restriction enzyme Aat II for Southern analyses (Figure S2A). The pilB1/C1 probe hybridized with DNA of all strains but strain specific variations were observed (Figure S2B). In five of the seven strains tested (R1, NRC-1, PHH1, PHH4, and SB3) the pilB1/C1 probe hybridized with two fragments of $4.1 \mathrm{kbp}$ and $3.3 \mathrm{kbp}$, corresponding to 


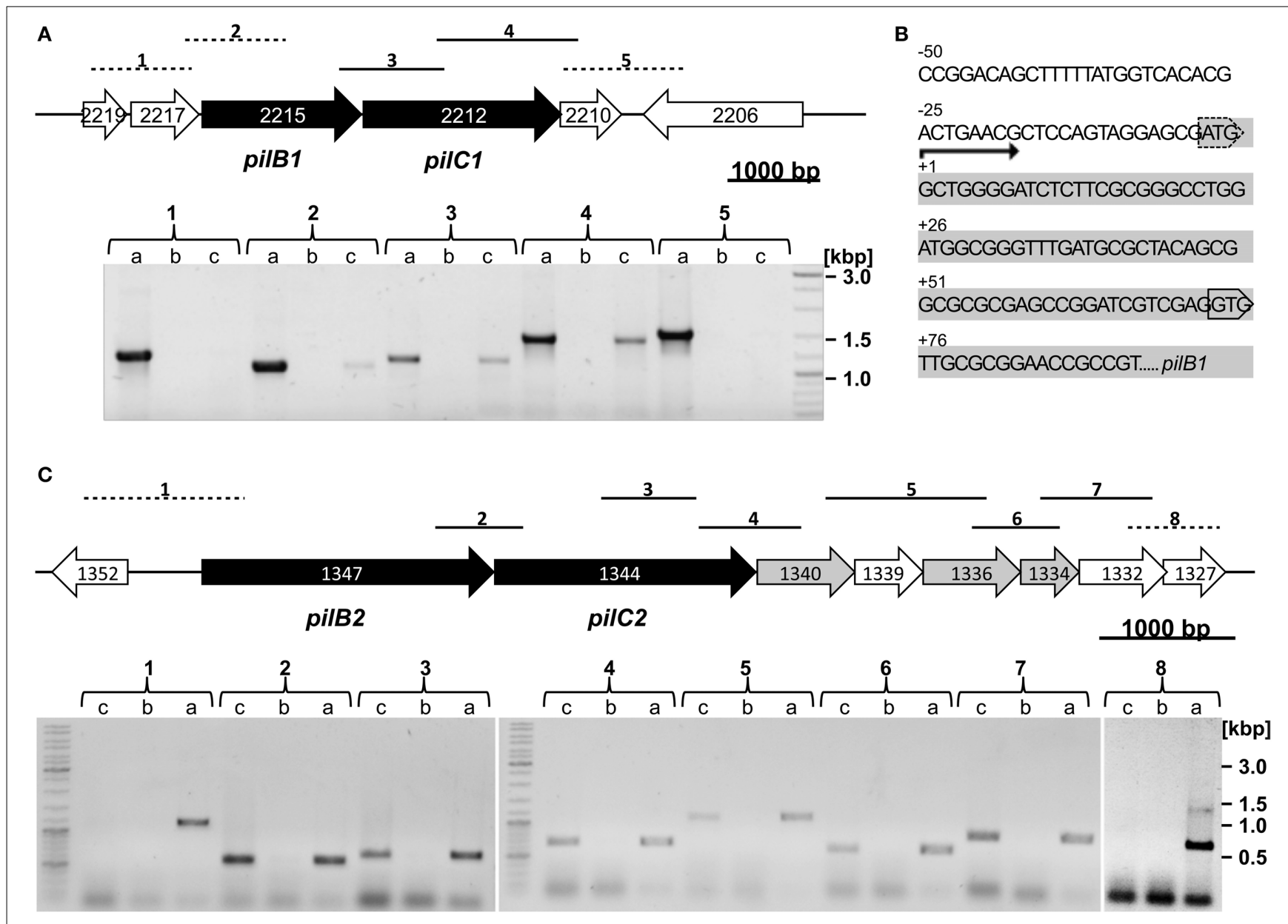

FIGURE 2 | Genomic regions and transcriptional analyses of the pil-1 and pil-2 loci. (A) Top: pil-1 locus with genes encoding the putative type IV pili assembly ATPase (pilB1) and putative transmembrane protein (pilC1) marked in black. Bottom: RT-PCR to determine a putative co-transcription using oligonucleotides amplifying fragments across the intergenic regions (brackets numbered 1 to 5 above the gel correspond to fragments 1 to 5 in the gene map; dashed lines, no co-transcription detected; full lines, co-transcription detected). For each pair of adjacent genes the three lanes in the gel represent (a) PCR product using $\mathrm{Hbt}$. salinarum R1 genomic DNA as template to validate the amplicon size and oligonucleotides specificity; (b) PCR product with RNA of planktonic
Hbt. salinarum R1 cells without reverse transcription; (c) RT-PCR product. (B) Upstream and 5' nucleotide sequence of pilB1 (OE2215R, shown in grey) and the AUG translation start codon predicted for OE2215R is marked by a dashed box. The transcription start site determined by primer extension is labeled +1 . The alternative GUG translation start codon is boxed. (C) Top: pil-2 locus with genes encoding the putative type IV pili assembly ATPase (pilB2) and putative transmembrane protein (pilC2) marked in black. Putative prepilin encoding genes are shown in grey. Bottom: RT-PCR experiment investigating co-transcription of the pil-2 genes similarly to pil-1 as explained in 2A. Brackets numbered 1 to 8 in the gel correspond to fragments 1 to 8 in the gene map. the theoretical sizes calculated from the genome sequence of Hbt. salinarum R1 (NC_010364.1). However, only one restriction fragment $(3.3 \mathrm{kbp})$ was detected for $\mathrm{Hbt}$. salinarum DSM $3754^{\mathrm{T}}$ and GN101. The pilB2 probe was expected to label a single fragment with a theoretical size of $4.3 \mathrm{kbp}$. This fragment was detected in Hbt. salinarum R1, DSM $3754^{\mathrm{T}}$, and the natural isolate GN101. Hbt. salinarum $\mathrm{PHH} 4$ contained a $7 \mathrm{~kb}$ fragment, and $\mathrm{PHH} 1$ and NRC-1 fragments larger than $10 \mathrm{kbp}$ (Figure $\mathrm{S} 2 \mathrm{C}$ ). Inspection of the genomic region encoding the pil-2 locus in NRC-1 (NC_002607) identified a $10 \mathrm{kbp}$ insertion in pilB2. The $10 \mathrm{~kb}$ insert contains the insertion elements ISH11 (993 bp) and ISH2 (204 bp), and sequence similarities to genes encoding halophage proteins (CopG protein, phage terminase, primase, integrase). The insert inactivates the pilB2 gene in NRC-1.
Blastn analyses using gene sequences of the transcriptional unit of pil-1 and pil-2 were performed to investigate the occurrence of these gene clusters in other archaeal genomes. The analyses indicated that the pil-1 gene locus $(4.4 \mathrm{kbp})$ is present in a broad range of other representatives of the Halobacteriaceae (Table S2). Regarding Hfx. volcanii D2 pil-1 is related to the gene locus encompassing the pilB3 and pilC3 genes, required for the PilA pilus biosynthesis (Esquivel and Pohlschröder, 2014). The core unit pilB1-C1 of the pil-1 locus is also present in the genomes of methanogenic and hyperthermophilic euryarchaeota but not in the genomes of crenarchaeota or other archaeal phyla. The pil2 locus $(6.9 \mathrm{kbp})$ is exclusively found in the genomes of other haloarchaeal strains not with other euryarchaeota (see Table S3). Low identities (query coverage $2 \%$ to $7 \%, e$-value 8 e- 05 to 3 e- 04 ) 
were found compared to high GC Gram ${ }^{+}$actinobacteria, like the biofilm forming Microbacterium xylanilyticum (Kim et al., 2005).

\section{COMPARATIVE qRT-PCR OF PLANKTONIC AND SURFACE ATTACHED CELLS}

The expression of the assembly/motor-ATPase encoding genes (flaI, pilB1, and pilB2) was investigated by quantitative reverse transcription polymerase chain reaction (qRT-PCR) in surface attached cells as well as planktonic cells of Hbt. salinarum R1. Total RNA was isolated from planktonic cells during the exponential growth phase $\left(\mathrm{OD}_{600} 0.3\right)$ and from surface attached cells (grown for 6 days). As control for the cDNA synthesis efficiency bgaH RNA ( $\beta$-D-galactosidase, HVO_A0326, Hfx. volcanii DS2), was added prior to the cDNA generation and used as an external standard. The oligonucleotides used for qRT-PCR are listed in Table S1. To investigate the general transcriptional activity in surface attached cells two "housekeeping" genes, rpoB1 (DNA-directed RNA polymerase subunit $\mathrm{B}^{\prime}, \mathrm{OE} 4741 \mathrm{R}$ ) and aef2 (translation elongation factor, OE4729R), were analyzed by qRTPCR and normalized to the external control bgaH (Figure 3A). For $r p o B 1$ and aef2 a 10 -fold reduction of the expression was observed in adherent cells compared to planktonic cells. Thus, the overall transcriptional activity is reduced in surface-attached cells of Hbt. salinarum R1 after 6 days of incubation. The relative expression of the pilB1 (OE2215R), pilB2 (OE1347R), and flaI (OE2380R) genes was determined by qRT-PCR to investigate the transcriptional activity of the corresponding gene loci in planktonic vs. surface attached cells, the $r p o B 1$ was used as internal standard. An induced transcriptional activity was observed for pilB1, pilB2, and flaI in surface attached cells compared to

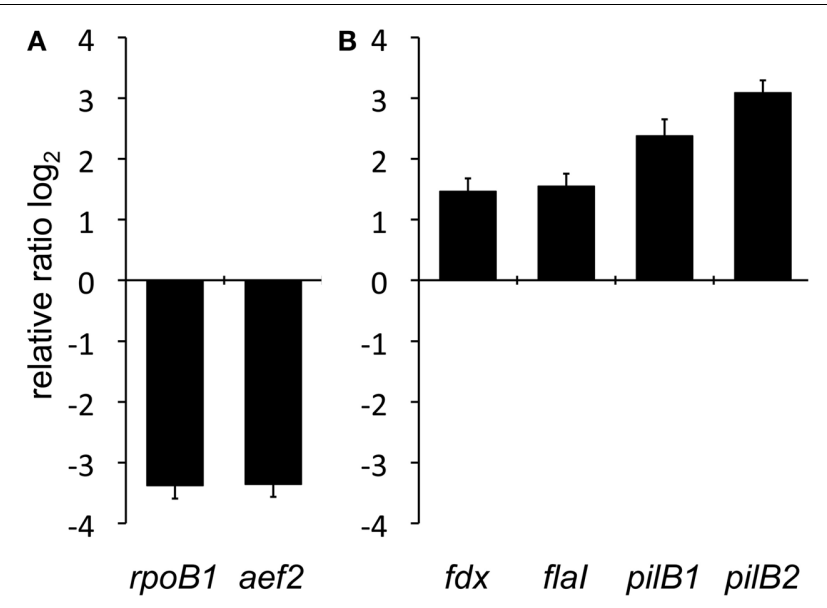

FIGURE 3 | Comparative qRT-PCR analyses of planktonic and surface attached cells. (A) Investigation of two representative housekeeping genes encoding RNA polymerase subunit $\mathrm{B}^{\prime}$ (rpoB1) and the translation elongation factor 2 (aef2). Relative expression was normalized to external standard bgaH RNA. (B) Relative transcriptional quantification of the assembly ATPase encoding genes of the archaellum (flal) and the type IV pilus biogenesis complexes pil-1 (pilB1) and pil-2 (pilB2) as well as the constitutively expressed ferredoxin gene $(f d x)$. The bars represent the fold change of gene expression shown in base 2 logarithmic scale in adherent cells compared to the planktonic state, which is defined by the baseline. planktonic cells (Figure 3B). The relative expressions of pilB1 and pilB2 were 5.2-fold respectively 8.5-fold enhanced in adherent cells compared to planktonic cells. In contrast, flaI showed a 2.9-fold induced transcription in adherent cells compared to planktonic cells which was similar to the gene $f d x$ (ferredoxin, OE4217R) with a 2.8-fold induced transcription. Ferredoxin is involved in cellular electron transfer and reported to be constitutively expressed (Twellmeyer et al., 2007). These data indicated a higher transcriptional activity of the pil-1 and pil-2 gene loci in surface attached cells. However, the number of cycles for the fluorescence signal to cross the threshold ( $C_{\mathrm{T}}$-value) was for pilB1 10 cycles lower $\left(C_{\mathrm{T}} 21\right.$ in surface attached cells) than for pilB2 $\left(C_{\mathrm{T}}\right.$ 31 in surface attached cells), indicating that the transcriptional activity of pilB1 is higher compared to pilB2.

\section{CONSTRUCTION AND PHENOTYPIC CHARACTERIZATION OF $\Delta$ flal AND $\Delta$ flal/D pilB1 MUTANTS}

Two deletion mutant strains were constructed from $\mathrm{Hbt}$. salinarum R1 to investigate a possible connection between the observed pili-like structures and the induced pilB1 expression in surface attached cells. The first target for a deletion was flaI (OE2380R) to generate cells lacking the archaella, analogous to studies on the archaella encoding fla-gene cluster of $\mathrm{Hbt}$. salinarum strain S9 showing that the deletion of the assembly ATPase corresponding gene flaI is sufficient to obtain non-archaellated cells (Patenge et al., 2001). In the second step the $\Delta$ flaI mutant strain was used to construct a $\Delta$ flaI/ $\Delta$ pilB1 double mutant (OE2380R/OE2215R) to investigate whether the pil-1 locus is involved in the biogenesis of the novel pili-like structures. A two step recombination method was used to construct markerless in-frame gene deletions in Hbt. salinarum R1 as described in Koch and Oesterhelt (2005). The construction of a $\Delta$ pilB1 single mutant was not successful so far. The deletions of flaI and flaI/pilB1 were identified by PCR using oligonucleotides flanking the genes of interest (Figure S3). The successful deletions were confirmed by sequencing of PCR amplified fragments derived from the deletion mutants, including the regions used for homologous recombination.

The presence of archaella with the parental strain and the deletion mutants was analyzed by a swimming motility assay. Semi solid plates with $0.3 \%(\mathrm{w} / \mathrm{v})$ agar were inoculated in the center with $10 \mu \mathrm{L}$ of an exponential culture. The motility halo was measured in $\mathrm{cm}$ after 3 days of incubation (Figure 4). Motility was

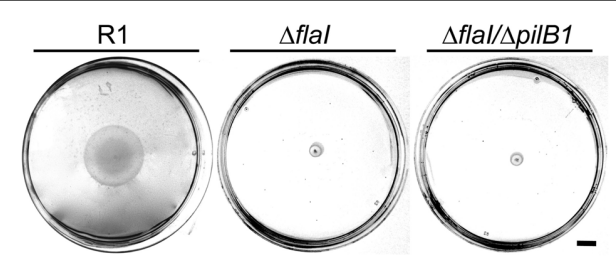

FIGURE 4 | Motility assay of $H$ bt. salinarum R1, $\Delta$ flal and $\Delta$ flal/ $\Delta$ pilB1 mutant strains. Swimming motility of $H$ bt. salinarum $\mathrm{R} 1$ as well as $\Delta$ flal and $\Delta$ flal/ $\Delta$ pilB1 mutant strains was analyzed in semi solid plates with $0.3 \%(\mathrm{w} / \mathrm{v})$ agar 3 days after cultivation at $42^{\circ} \mathrm{C}$. The scale bar on the right is $1 \mathrm{~cm}$. 
observed with the Hbt. salinarum R1 parental strain (motility halo $4.2 \pm 1.2 \mathrm{~cm}, n=19)$. In contrast, both deletion mutant strains $\Delta$ flaI $/ \Delta$ pilB1 $(0.7 \pm 0.1 \mathrm{~cm}, n=19)$ and $\Delta$ flaI $(0.7 \pm 0.2 \mathrm{~cm}, n=$ 19) did not show any motility, demonstrating that flaI is required for swimming. This is in accordance with the data by Patenge et al. (2001). However, with surface attached $\Delta$ flaI cells pili-like surface structures were observed by electron microscopy (Figure 5A). In comparison to the Hbt. salinarum R1 parental strain (see Figure 1) the number of surface structures observed with the cells of the $\Delta$ flaI mutant were reduced to $10-30 \%$. For planktonic cells of the non-archaellated $\Delta$ flaI mutant a maximum of 2 to 3 structures were visible per cell (data not shown). The diameters of 100 surface structures found with the $\Delta$ flaI mutant were determined. The frequency distribution indicated a predominant diameter of 7 to $8 \mathrm{~nm}$ found with $31 \%$ of the pili-like structures (Figure 5B). The average diameter was calculated to be $7.6 \pm$ $0.8 \mathrm{~nm}$ (calculated on the categories 6 to $9 \mathrm{~nm}, n=66$ ), which is identical to the average diameter determined previously for the novel pili-like structures (Figure 1) of the parental strain. No pililike structures were observed with any cells of the $\Delta$ flaI/ $\Delta$ pilB1 mutant, neither with planktonic nor surface attached cells of the entire culture (Figure 5A). These results demonstrated that pilB1 is required for the assembly of the novel pili-like structures.

To determine a possible role of the novel pili-like structures in surface adhesion, cells of Hbt. salinarum R1 parental strain,
$\Delta$ flaI and $\Delta$ flaI/ $\Delta$ pilB1 mutants were grown on cover slips for 10 days. Prior to microscopic analyses the overgrown cover slips were stringently washed to remove all non-surface attached cells. A monolayer of surface attached cells was observed for $\mathrm{Hbt}$. salinarum $\mathrm{R} 1$ and the $\Delta$ flaI mutant strains. In contrast, the number of surface attached cells was strongly reduced with the $\Delta$ flaI/ $\Delta$ pilB1 mutant where only a few cells attached to the surface (Figure 5C). To quantify these findings the surface coverage percentage of six photographs was determined for the parental and the mutant strains using ImageJ. The surface coverage of the non-archaellated $\Delta$ flaI mutants added up to $44 \% \pm 3.6$ and was therefore higher $\left[t_{(12)}=3.3, p<0.01\right]$ than the value determined for the parental strain Hbt. salinarum R1 $(36 \% \pm 4.0)$. The surface coverage observed with the non-archaellated and nonpiliated cells of the $\Delta$ flaI/ $\Delta$ pilB1 mutant was 10 -fold reduced [ $4 \%$ $\left.\pm 1.3, t_{(12)}=16.5, p<0.001\right]$.

\section{DISCUSSION}

Surface adhesion of the moderate halophile $H f x$. volcanii DS2 is solely dependent on pili while archaella are not required (Tripepi et al., 2010; Esquivel et al., 2013). For the extremely halophilic archaeon $\mathrm{Hbt}$. salinarum structures mediating adhesion have not been described yet. Cells of Hbt. salinarum possess polar archaella mediating the swimming motility (Alam and Oesterhelt, 1984). Their possible role in surface adhesion as well as the presence of further surface structures besides archaella were unclear. A first
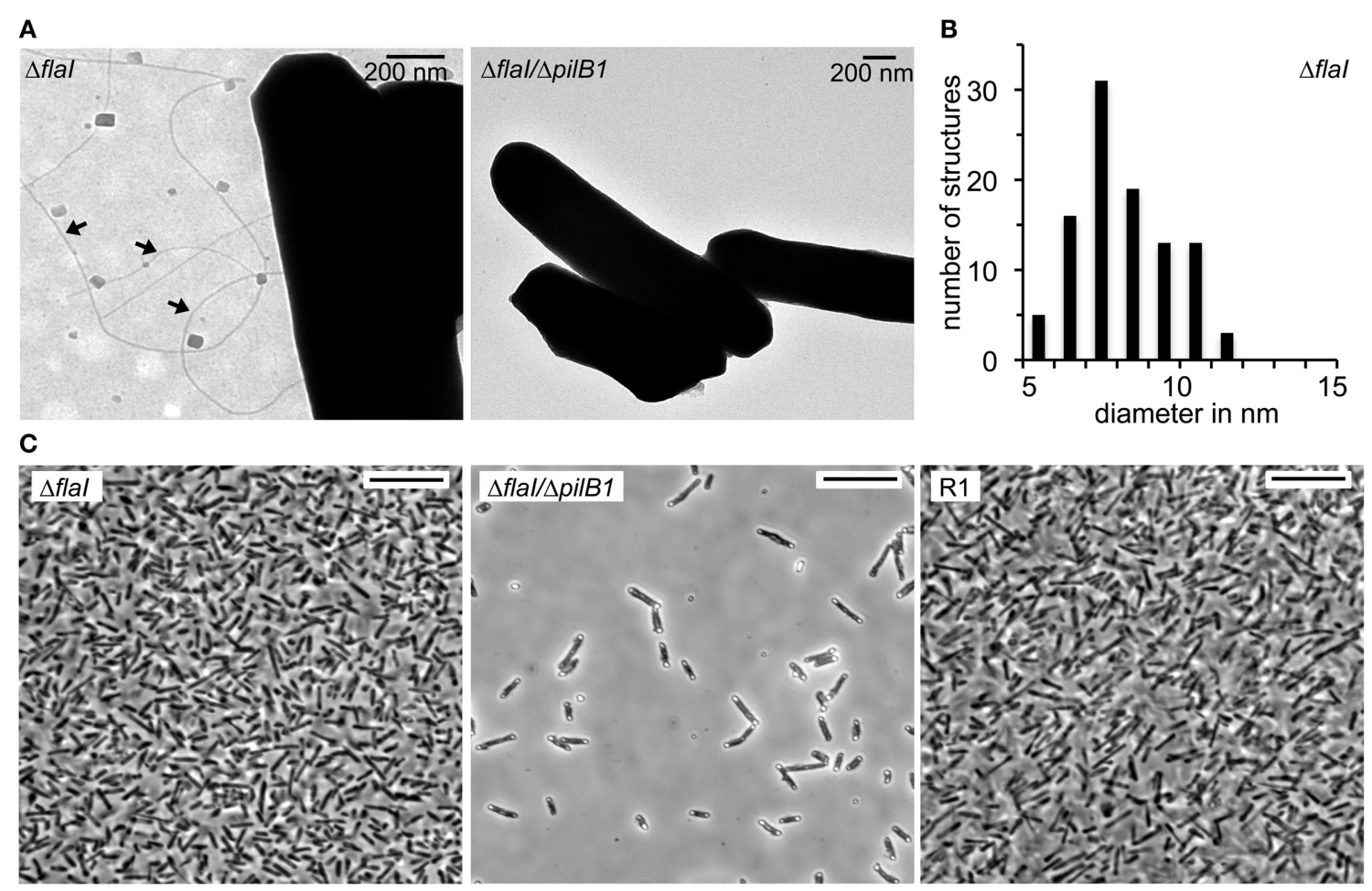

FIGURE 5 | Phenotypic characterization of the Hbt. salinarum R1, $\Delta$ flal and $\Delta$ flal/ $\Delta$ pilB1 mutant strains. (A) Transmission electron micrographs of surface attached cells on carbon coated gold grids after 10 days of cultivation at $42^{\circ} \mathrm{C}$. Pili-like surface structures observed with $\Delta$ flal are labeled with arrows.
(B) Frequency distribution of 100 filaments diameters in $\mathrm{nm}$ found with the $\Delta$ flal mutant. (C) Light micrographs of $\mathrm{Hbt}$. salinarum R1 and mutant strains attached to a glass surface after 10 days of cultivation at $42^{\circ} \mathrm{C}$. Cells not attached to the surface were removed by stringent washing. Scale bars are $10 \mu \mathrm{m}$. 
hint for the existence of various filamentous structures came from TEM analyses of surface attached cells of Hbt. salinarum DSM $3754^{\mathrm{T}}$ (Fröls et al., 2012).

In this report we determined that Hbt. salinarum $\mathrm{R} 1$ possesses additional surface structures crucial for surface adhesion. The pili-like structures of 7 to $8 \mathrm{~nm}$ are thinner compared to the Aap (archaeal adhesive pili) of Sulfolobus acidocaldarius with $10 \mathrm{~nm}$ and the type IV pili of $M$. maripaludis with $8.5 \mathrm{~nm}$ in diameter (Wang et al., 2008; Henche et al., 2012). Comparison of filamentous surface structures found with surface attached cells of the non-archaellated $\Delta$ flaI deletion mutant and the parental strain showed that these novel pili-like structures represent approximately one-third of the total cell appendages, illustrating that the archaella are the major surface structures in Hbt. salinarum R1. For planktonic cells the total number of these pili-like surface structures is reduced to a maximum of 2 to 3 structures per cell, which explains why the novel structures were not observed before.

Within the genome sequence of Hbt. salinarum R1 two putative type IV pili gene loci (pil-1 and pil-2) were present. Transcriptional analyses of the pil-1 locus identified a $5^{\prime}$-UTR with an alternative GUG translation start codon, which is found in $16 \%$ of the genes in Hbt. salinarum NRC-1 (Torarinsson et al., 2005). In addition, a putative Shine-Dalgarno element cGAGccGg [consensus sequence for Hbt. salinarum GGAGGUGA (Mankin et al., 1985)] was found located 9 nt upstream of the alternative GUG translation start codon, which is in good agreement with the distance for Shine-Dalgarno sequences present in Hbt. salinarum PHH1 (Sartorius-Neef and Pfeifer, 2004). Reporter gene studies with the gene encoding the Hbt. salinarum $\mathrm{PHH} 1$ gas vesicle protein $\mathrm{H}$ showed that this SD sequence influences the translation efficiency (Sartorius-Neef and Pfeifer, 2004). In the case of pil-1 a putative stem-loop structure was predicted for the $5^{\prime}$-UTR, masking the Shine-Dalgarno sequence and the GUG translation start codon, which might effect the pil-1 translation efficiency, too.

Comparative genome analyses showed that the core unit of the pil-1 locus is also present in genomes of other euryarcheota and presumably represents a general system for surface adhesion. In contrast, the pil-2 locus was solely present in haloarchaeal species. It is possible that this region was received from bacteria by lateral gene transfer, since the pil-2 locus exhibits weak identities with genome sequences of actinobacteria. Comparative analyses of archaeal and bacterial genomes identified 2264 bacterial gene acquisitions by lateral gene transfer in Archaea and over 1000 in Haloarchaea, most of them derived from Actinobacteria (NelsonSathi et al., 2012, 2014). Representatives of these tolerate the high salt concentrations occurring in saline environments (Hamedi et al., 2013).

Inspection of the particular genomic region in $\mathrm{Hbt}$. salinarum NRC-1 identified an additional $10 \mathrm{kbp}$ insert in the pilB2 gene inactivating the pil-2 locus. This region represents one of the 12 differences between the chromosomes of Hbt. salinarum R1 and NRC-1 (Pfeiffer et al., 2008b) and contains ISH elements and phage-specific sequences. It is flanked by an 8 bp duplication in NRC-1, that is only present as one copy in the Hbt. salinarum R1, DL-1, and Hfx. volcanii D2, but not with the genomic pilB2 regions of Natronomonas pharaonis, or Salinarchaeum sp., suggesting a re-deletion of the region in some of the haloarchaeal strains and the possible reconstitution of pilB2.

The results of the quantitative reverse transcription PCR analyses implied a specific transcriptional up-regulation of the pil-1 and pil-2 loci in surface attached cells of Hbt. salinarum $\mathrm{R} 1$. Whether this is regulated directly by the surface contact or indirectly by changing growth conditions (for instance limited oxygen or nutrient supply) is not yet clear. Motility in $H f x$. volcanii can be altered under certain medium conditions. Archaella-dependent swimming motility is observed with complex or defined medium containing casamino acids but not with defined medium (Tripepi et al., 2010). For Hbt. salinarum R1 no significant changes in motility or surface adhesion were observed so far under anaerobic conditions or in response to the reduction of the nutrient source (Völkel and Fröls, unpublished results).

The phenotypic characterization of the $\Delta$ flaI and $\Delta$ flaI/ $\Delta$ pilB1 deletion mutants indicated that a functional pil-1 locus is essential for the formation of the novel pili-like filamentous structures. However, additional studies like the constructions of a pilB1 single deletion strain and its phenotypic characterizations are required, as well as the preparation of the pili structures to analyze their pilin composition. It is questionable which pilins form the surface structure since no putative pilins are encoded in the surrounding genomic region of the pil-1 locus. Within the genome sequence of $\mathrm{Hbt}$. salinarum R1 more than 30 putative pilin encoding genes were predicted (Losensky and Fröls, unpublished results). Which ones of these putative pilins are expressed and assembled into pili structures is not known so far. For $H f x$. volcanii D2 six pilins (PilA1-6) encoded in different genomic regions were identified. Each of the six pilins alone or in combination is sufficient for the biosynthesis of pili mediating surface adhesion (Esquivel et al., 2013).

The absence of pili-like structures and archaella leads to an impaired surface adhesion phenotype while in the absence of the archaella surface adhesion was increased. We conclude that the pili-like structures and not the archaella are crucial for surface adhesion of Hbt. salinarum R1. Nevertheless, we cannot exclude that the archaella are involved in the initial attachment to the surface, as assumed for S. acidocaldarius (Henche et al., 2012). In bacteria the flagella are important to mediate the initial reversible attachment to overcome the hydrodynamic boundary layer and repulsive forces. Moreover, a reduced flagellar rotation triggered the transcriptional activation of extracellular polymeric substances by modulation of the second messenger cyclic diguanylate (Petrova and Sauer, 2012).

On the contrary, in the absence of the archaella and pililike structures low amounts of cells still attached to the surface, indicating that additional surface structures or mechanisms were present. Additional pili-like structures are possibly expressed in minor amounts by the pil-2 locus, which encompasses three putative pilins. However, due to the internal stop codon within pilC2 it is questionable whether the pil-2 locus is functional. Surface adhesion might also be mediated by amyloid adhesins (i.e., short fibers formed by an extracellular protein) present with several bacterial biofilm forming species (Larsen et al., 2007). In Archaea amyloid proteins are present in the large dense cell clusters and 
tower like biofilm structures of $H f x$. volcanii D2 (Chimileski et al., 2014).

Overall the phenotypic characterization of the deletion mutants indicated that the novel pili-like structures are crucial for surface adhesion of Hbt. salinarum R1, but the structures themselves still remain to be characterized on the genetic and protein levels.

\section{ACKNOWLEDGMENTS}

Arnulf Kletzin and Friedhelm Pfeiffer are thanked for fruitful discussions. We thank the reviewers for valuable comments on the manuscript.

\section{SUPPLEMENTARY MATERIAL}

The Supplementary Material for this article can be found online at: http://www.frontiersin.org/journal/10.3389/fmicb.2014. 00755/abstract

\section{REFERENCES}

Alam, M., and Oesterhelt, D. (1984). Morphology, function and isolation of halobacterial flagella. J. Mol. Biol. 176, 459-475. doi: 10.1016/00222836(84)90172-4

Bleiholder, A., Frommherz, R., Teufel, K., and Pfeifer, F. (2012). Expression of multiple $\mathrm{tfb}$ genes in different Halobacterium salinarum strains and interaction of TFB with transcriptional activator GvpE. Arch. Microbiol. 194, 269-279. doi: 10.1007/s00203-011-0756-z

Chan, P. P., Holmes, A. D., Smith, A. M., Tran, D., and Lowe, T. M. (2012). The UCSC Archaeal Genome Browser: 2012 update. Nucleic Acids Res. 40, D646-D652. doi: 10.1093/nar/gkr990

Chimileski, S., Franklin, M. J., and Papke, R. T. (2014). Biofilms formed by the archaeon Haloferax volcanii exhibit cellular differentiation and social motility, and facilitate horizontal gene transfer. BMC Biol. 12:65. doi: 10.1186/s12915014-0065-5

Chomczynski, P., and Sacchi, N. (2006). The single-step method of RNA isolation by acid guanidinium thiocyanate-phenol-chloroform extraction: twentysomething years on. Nat. Protoc. 1, 581-585. doi: 10.1038/nprot.2006.83

Cohen-Krausz, S., and Trachtenberg, S. (2002). The structure of the archeabacterial flagellar filament of the extreme halophile Halobacterium salinarum R1M1 and its relation to eubacterial flagellar filaments and type IV pili. J. Mol. Biol. 321, 383-395. doi: 10.1016/S0022-2836(02)00616-2

Dyall-Smith, M. L. (2008). The Halohandbook: Protocols for Halobacterial Genetics. Available online at: http://www.haloarchaea.com/resources/halohandbook/ Halohandbook_2008_v7.pdf

Ebert, K., Goebel, W., and Pfeifer, F. (1984). Homologies between heterogeneous extrachromosomal DNA populations of Halobacterium halobium and four new isolates. Mol. Gen. Genet. 194, 91-97. doi: 10.1007/BF00383502

Esquivel, R. N., and Pohlschröder, M. (2014). A conserved type IV pilin signal peptide H-domain is critical for the post-translational regulation of flagelladependent motility. Mol. Microbiol. 93, 494-504. doi: 10.1111/mmi.12673

Esquivel, R. N., Xu, R., and Pohlschröder, M. (2013). Novel archaeal adhesion pilins with a conserved $\mathrm{N}$ terminus. J. Bacteriol. 195, 3808-3818. doi: 10.1128/JB.00572-13

Fröls, S., Dyall-Smith, M., and Pfeifer, F. (2012). Biofilm formation by haloarchaea. Environ. Microbiol. 14, 3159-3174. doi: 10.1111/j.1462-2920.2012.02895.x

Gruber, C., Legat, A., Pfaffenhuemer, M., Radax, C., Weidler, G., Busse, H. J., et al. (2004). Halobacterium noricense sp. nov., an archaeal isolate from a bore core of an alpine Permian salt deposit, classification of Halobacterium sp. NRC1 as a strain of Hbt. salinarum and emended description of Hbt. salinarum. Extremophiles 8, 431-439. doi: 10.1007/s00792-004-0403-6

Hamedi, J., Mohammadipanah, F., and Ventosa, A. (2013). Systematic and biotechnological aspects of halophilic and halotolerant actinomycetes. Extremophiles 17, 1-13. doi: 10.1007/s00792-012-0493-5

Henche, A. L., Ghosh, A., Yu, X., Jeske, T., Egelman, E., and Albers, S. V. (2012). Structure and function of the adhesive type IV pilus of Sulfolobus acidocaldarius. Environ. Microbiol. 14, 3188-3202. doi: 10.1111/j.1462-2920.2012. 02898.x
Henneberger, R., Moissl, C., Amann, T., Rudolph, C., and Huber, R. (2006). New insights into the lifestyle of the cold-loving SM1 euryarchaeon: natural growth as a monospecies biofilm in the subsurface. Appl. Environ. Microbiol. 72, 192-199. doi: 10.1128/AEM.72.1.192-199.2006

Jarrell, K. F., and Albers, S. V. (2012). The archaellum: an old motility structure with a new name. Trends Microbiol. 20, 307-312. doi: 10.1016/j.tim.2012.04.007

Jarrell, K. F., Stark, M., Nair, D. B., and Chong, J. P. (2011). Flagella and pili are both necessary for efficient attachment of Methanococcus maripaludis to surfaces. FEMS Microbiol. Lett. 319, 44-50. doi: 10.1111/j.1574-6968.2011.02264.x

Kim, K. K., Park, H. Y., Park, W., Kim, I. S., and Lee, S. T. (2005). Microbacterium xylanilyticum sp. nov., a xylan-degrading bacterium isolated from a biofilm. Int. J. Syst. Evol. Microbiol. 55, 2075-2079. doi: 10.1099/ijs.0.63706-0

Koch, M. K., and Oesterhelt, D. (2005). MpcT is the transducer for membrane potential changes in Halobacterium salinarum. Mol. Microbiol. 55, 1681-1694. doi: 10.1111/j.1365-2958.2005.04516.x

Krogh, A., Larsson, B., Von Heijne, G., and Sonnhammer, E. L. (2001). Predicting transmembrane protein topology with a hidden Markov model: application to complete genomes. J. Mol. Biol. 305, 567-580. doi: 10.1006/jmbi.2000.4315

Larsen, P., Nielsen, J. L., Dueholm, M. S., Wetzel, R., Otzen, D., and Nielsen, P. H. (2007). Amyloid adhesins are abundant in natural biofilms. Environ. Microbiol. 9, 3077-3090. doi: 10.1111/j.1462-2920.2007.01418.x

Lassak, K., Ghosh, A., and Albers, S. V. (2012). Diversity, assembly and regulation of archaeal type IV pili-like and non-type-IV pili-like surface structures. Res. Microbiol. 163, 630-644. doi: 10.1016/j.resmic.2012.10.024

Letunic, I., Doerks, T., and Bork, P. (2012). SMART 7: recent updates to the protein domain annotation resource. Nucleic Acids Res. 40, D302-D305. doi: 10.1093/nar/gkr931

Mankin, A. S., Kagramanova, V. K., Teterina, N. L., Rubtsov, P. M., Belova, E. N., Kopylov, A. M., et al. (1985). The nucleotide sequence of the gene coding for the 16S rRNA from the archaebacterium Halobacterium halobium. Gene 37, 181-189. doi: 10.1016/0378-1119(85)90271-9

Moissl, C., Rachel, R., Briegel, A., Engelhardt, H., and Huber, R. (2005). The unique structure of archaeal 'hami', highly complex cell appendages with nano-grappling hooks. Mol. Microbiol. 56, 361-370. doi: 10.1111/j.13652958.2005.04294.x

NCBI Resource Coordinators (2014). Database resources of the National Center for biotechnology information. Nucleic Acids Res. 42, D7-D17. doi: 10.1093/nar/gkt1146

Näther, D. J., Rachel, R., Wanner, G., and Wirth, R. (2006). Flagella of Pyrococcus furiosus: multifunctional organelles, made for swimming, adhesion to various surfaces, and cell-cell contacts. J. Bacteriol. 188, 6915-6923. doi: 10.1128/JB.00527-06

Nelson-Sathi, S., Dagan, T., Landan, G., Janssen, A., Steel, M., McInerney, J. O., et al. (2012). Acquisition of 1,000 eubacterial genes physiologically transformed a methanogen at the origin of Haloarchaea. Proc. Natl. Acad. Sci. U.S.A. 109, 20537-20542. doi: 10.1073/pnas.1209119109

Nelson-Sathi, S., Sousa, F. L., Roettger, M., Lozada-Chavez, N., Thiergart, T., Janssen, A., et al. (2014). Origins of major archaeal clades correspond to gene acquisitions from bacteria. Nature 13805 doi: 10.1038/nature13805. [Epub ahead of print].

Patenge, N., Berendes, A., Engelhardt, H., Schuster, S. C., and Oesterhelt, D. (2001). The fla gene cluster is involved in the biogenesis of flagella in Halobacterium salinarum. Mol. Microbiol. 41, 653-663. doi: 10.1046/j.1365-2958.2001.02542.x

Peabody, C. R., Chung, Y. J., Yen, M. R., Vidal-Ingigliardi, D., Pugsley, A. P., and Saier, M. H. Jr. (2003). Type II protein secretion and its relationship to bacterial type IV pili and archaeal flagella. Microbiology 149, 3051-3072. doi: 10.1099/mic.0.26364-0

Petrova, O. E., and Sauer, K. (2012). Sticky situations: key components that control bacterial surface attachment. J. Bacteriol. 194, 2413-2425. doi: 10.1128/JB.00003-12

Pfeifer, F., and Blaseio, U. (1989). Insertion elements and deletion formation in a halophilic archaebacterium. J. Bacteriol. 171, 5135-5140.

Pfeifer, F., Blaseio, U., and Ghahraman, P. (1988). Dynamic plasmid populations in Halobacterium halobium. J. Bacteriol. 170, 3718-3724.

Pfeiffer, F., Broicher, A., Gillich, T., Klee, K., Mejia, J., Rampp, M., et al. (2008a). Genome information management and integrated data analysis with HaloLex. Arch. Microbiol. 190, 281-299. doi: 10.1007/s00203-008-0389-Z

Pfeiffer, F., Schuster, S. C., Broicher, A., Falb, M., Palm, P., Rodewald, K., et al. (2008b). Evolution in the laboratory: the genome of Halobacterium salinarum 
strain R1 compared to that of strain NRC-1. Genomics 91, 335-346. doi: 10.1016/j.ygeno.2008.01.001

Pohlschröder, M., Ghosh, A., Tripepi, M., and Albers, S. V. (2011). Archaeal type IV pilus-like structures-evolutionarily conserved prokaryotic surface organelles. Curr. Opin. Microbiol. 14, 357-363. doi: 10.1016/j.mib.2011.03.002

Sartorius-Neef, S., and Pfeifer, F. (2004). In vivo studies on putative Shine-Dalgarno sequences of the halophilic archaeon Halobacterium salinarum. Mol. Microbiol. 51, 579-588. doi: 10.1046/j.1365-2958.2003.03858.x

Schmittgen, T. D., and Livak, K. J. (2008). Analyzing real-time PCR data by the comparative $\mathrm{C}(\mathrm{T})$ method. Nat. Protoc. 3, 1101-1108. doi: 10.1038/nprot.2008.73

Schneider, K. L., Pollard, K. S., Baertsch, R., Pohl, A., and Lowe, T. M. (2006). The UCSC Archaeal Genome Browser. Nucleic Acids Res. 34, D407-D410. doi: 10.1093/nar/gkj134

Schultz, J., Milpetz, F., Bork, P., and Ponting, C. P. (1998). SMART, a simple modular architecture research tool: identification of signaling domains. Proc. Natl. Acad. Sci. U.S.A. 95, 5857-5864. doi: 10.1073/pnas.95.11.5857

Streif, S., Staudinger, W. F., Marwan, W., and Oesterhelt, D. (2008). Flagellar rotation in the archaeon Halobacterium salinarum depends on ATP. J. Mol. Biol. 384, 1-8. doi: 10.1016/j.jmb.2008.08.057

Szabo, Z., Stahl, A. O., Albers, S. V., Kissinger, J. C., Driessen, A. J., and Pohlschröder, M. (2007). Identification of diverse archaeal proteins with class III signal peptides cleaved by distinct archaeal prepilin peptidases. J. Bacteriol. 189, 772-778. doi: 10.1128/JB.01547-06

Thoma, C., Frank, M., Rachel, R., Schmid, S., Näther, D., Wanner, G., et al. (2008). The Mth60 fimbriae of Methanothermobacter thermoautotrophicus are functional adhesins. Environ. Microbiol. 10, 2785-2795. doi: 10.1111/j.14622920.2008.01698.x

Torarinsson, E., Klenk, H. P., and Garrett, R. A. (2005). Divergent transcriptional and translational signals in Archaea. Environ. Microbiol. 7, 47-54. doi: 10.1111/j.1462-2920.2004.00674.x

Tripepi, M., Imam, S., and Pohlschröder, M. (2010). Haloferax volcanii flagella are required for motility but are not involved in PibD-dependent surface adhesion. J. Bacteriol. 192, 3093-3102. doi: 10.1128/JB.00133-10
Twellmeyer, J., Wende, A., Wolfertz, J., Pfeiffer, F., Panhuysen, M., Zaigler, A., et al. (2007). Microarray analysis in the archaeon Halobacterium salinarum strain R1. PLoS ONE 2:e1064. doi: 10.1371/journal.pone.0001064

Wang, C., Lee, J., Deng, Y., Tao, F., and Zhang, L. (2012). ARF-TSS: an alternative method for identification of transcription start site in bacteria. Biotechniques 1-3. doi: 10.2144/000113858. [Epub ahead of print].

Wang, Y. A., Yu, X., Ng, S. Y., Jarrell, K. F., and Egelman, E. H. (2008). The structure of an archaeal pilus. J. Mol. Biol. 381, 456-466. doi: 10.1016/j.jmb.2008. 06.017

Zolghadr, B., Klingl, A., Koerdt, A., Driessen, A. J., Rachel, R., and Albers, S. V. (2010). Appendage-mediated surface adherence of Sulfolobus solfataricus. J. Bacteriol. 192, 104-110. doi: 10.1128/JB.01061-09

Zuker, M. (2003). Mfold web server for nucleic acid folding and hybridization prediction. Nucleic Acids Res. 31, 3406-3415. doi: 10.1093/nar/ gkg595

Conflict of Interest Statement: The authors declare that the research was conducted in the absence of any commercial or financial relationships that could be construed as a potential conflict of interest.

Received: 30 September 2014; accepted: 11 December 2014; published online: 13 January 2015.

Citation: Losensky G, Vidakovic L, Klingl A, Pfeifer F and Fröls S (2015) Novel pililike surface structures of Halobacterium salinarum strain R1 are crucial for surface adhesion. Front. Microbiol. 5:755. doi: 10.3389/fmicb.2014.00755

This article was submitted to Microbial Physiology and Metabolism, a section of the journal Frontiers in Microbiology.

Copyright (c) 2015 Losensky, Vidakovic, Klingl, Pfeifer and Fröls. This is an openaccess article distributed under the terms of the Creative Commons Attribution License (CC BY). The use, distribution or reproduction in other forums is permitted, provided the original author(s) or licensor are credited and that the original publication in this journal is cited, in accordance with accepted academic practice. No use, distribution or reproduction is permitted which does not comply with these terms. 